九州大学学術情報リポジトリ

Kyushu University Institutional Repository

Uncommon Keeled Ammonites from the Upper Cretaceous of Hokkaido and Saghalien : Studies of the Cretaceous Ammonites from Hokkaido and Saghalien- XXII

Matsumoto, Tatsuro

Faculty of Science, Kyushu University

https://doi. org/10.5109/1544086

出版情報：九州大學理學部紀要：Series D, Geology. 20 (2)，pp.305-317，1970-11-10. Faculty of Science, Kyushu University バージョン：

権利関係 : 
Mem. Fac. Sci., Kyushu Univ., Ser. D, Geology, Vol. XX, No. 2, pp. $305-317$, text-figs. $1-5$, pls. $48-49$, November 10,1970

\title{
Uncommon Keeled Ammonites from the Upper Cretaceous of Hokkaido and Saghalien
}

\author{
(Studies of the Cretaceous Ammonites from \\ Hokkaido and Saghalien-XXII)
}

By

Tatsuro MATSUMOTO

\begin{abstract}
I describe in this paper two uncommon keeled ammonites, from the Upper Cretaceous of Hokkaido and South Saghalien, which have been unsettled in their systematic position. One is Pseudobarroisiceras nagaoi Shimizu, which is closely allied to a weakly ornate variety of Barroisiceras onilahyense but has an entire keel. It is assigned to the Barroisiceratinae, since it did not further give rise to other smoothly keeled ammonites to be grouped with it and since there are certain barroisiceratine ammonites which tend to show smoothing of the serrate keel in more or less late growth-stages. The similarity of Pseudobarroisiceras to Pseudoschloenbachia is superficial, because the latter is best ascribed to the Muniericeratidae, together with Texasia, Lehmaniceras, etc. The other is a new species of Hourcquia, which is allied to but less typical than $H$. mirabilis ColligNoN. It looks as if it were another smoothly keeled barroisiceratine ammonite related to Subbarroisiceras mahafalense BASSE. It is also superficially similar to Diaziceras tissotiaeforme SPATH, which, however, is a member of the Lenticeratinae.
\end{abstract}

\section{Introduction}

While I am publishing serially a monograph of the Collignoniceratidae from Hokkaido (1965-70), I am aware of the existence of two uncommon keeled ammonite species which are questionable in their systematic position. Although they are represented by a small number of specimens in the Cretaceous of Hokkaido and Saghalien, they deserve description and discussion for further improvement of our knowledge. In connexion with them comments are also given to certain other Upper Cretaceous keeled ammonites. The described and discussed keeled ammonites would exemplify the homoeomorphy between different families.

\section{Systematic Descriptions}

Family Collignoniceratidae

Genus Pseudobarroisiceras SHIMIZU, 1932

Type-species.-Pseudobarroisiceras nagaoi SHImizu, 1932 (original designa- 
tion).

Diagnosis. - The shell is small to moderate in size, involute and fairly narrowly umbilicate. The whorl is higher than broad, with a fastigate venter and a smooth, unserrate keel. The ribs are more flexiradiate on the inner whorls and less so on the outer one. They normally spring in twos or threes from the umbilical tubercles but sometimes the secondary ribs are inserted. Every rib is elevated to a rounded tubercle, or swollen, at the ventrolateral shoulder, where it is bent forward but weakened and finally disappears near the keel. The ornament may be weakened on the adult body-whorl. The suture is rather simple in the immature stages and moderately incised in the adult stage. It consists of E, $\mathrm{L}, \mathrm{U}_{2}, \mathrm{U}_{4}, \mathrm{U}_{5}(=\mathrm{S}), \mathrm{U}_{3}, \mathrm{U}_{1}$, and I. Its pattern is generally of Barroisiceras type.

Remarks.-In addition to the type-species, Schloenbachia boreaui DE GROsSOUVRe, 1894, may be referable to Pseudobarroisiceras, as SHIMIZU (1932) thought, but the suture of that species is not known (see MATsumoto, 1965, p. 73).

Comparison.-Pseudobarroisiceras is similar to Barroisiceras in many respects, but has a smooth keel instead of a serrate one. The ventrolateral tubercles stand as distinct clavae in Barroisiceras, whereas they are rounded or simply swollen at the bending point of the ribs in Pseudobarroisiceras. The suture of Pseudobarroisiceras is essentially similar to that of Barroisiceras, although there may be a considerable variation in details.

The distinction between Pseudobarroisiceras and Reesidites is clearer, as can be seen between the type-species (see description below).

Lymaniceras MATSUMOTO, 1965, established on the type-species, L. planulatum MATSUmoto, 1965, from the Upper Turonian of Hokkaido, is somewhat similar to Pseudobarroisiceras in the mode of ribbing and tubercles and high whorls, with a fastigate venter, but there is an unmistakable distinction in that the former has a less involute shell, with a wider umbilicus, a finely crenulate keel like that of Prionocyclus, and simpler sutures with more massive and less deeply incised saddles.

Pseudobarroisiceras is apparently similar to Pseudoschloenbachia SPATH, 1921, but the distinction in the pattern of suture is significant (see p. 309).

\section{Pseudobarroisiceras nagaoi SHIMIZU}

Pl. 48, Fig. 1; Pl. 49, Fig. 1; Text-figs. 1-3

1932. Pseudobarroisiceras nagaoi ShImizu, Japan. Jour. Geol. Geogr., vol.10, p. 3, pl. 1, figs. 1, 2, 4-8.

Material.-Holotype, IGPS. 36853 (previously registered as 49432), from the lower reaches of the Wakkawen, a tributary of the Abeshinai, Teshio Province, northwestern Hokkaido. This is a small, somewhat deformed specimen. A larger example in the subsequent collection (hypotype), GK. H5461 $[=\mathrm{T}$. Muramoto Coll. 9300 donated to Kyushu University], from loc. Ik 1003, Ikushumbets valley, Ishikari Province, central Hokkaido.

Specific characters.-The shell is about $100 \mathrm{~mm}$. in diameter at the full-grown 


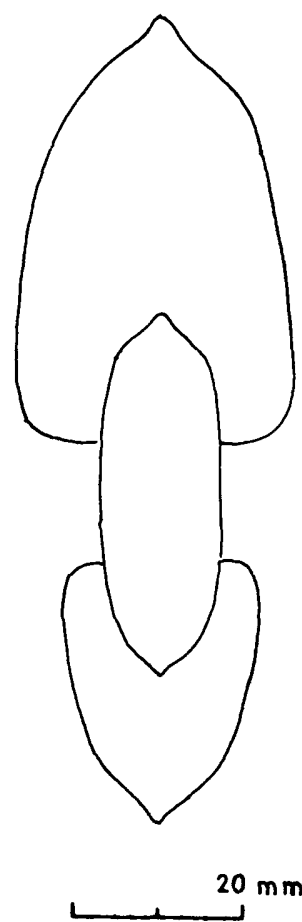

Fig. 1. Pseudobarroisiceras nagaoi ShIMIZU. Diagrammatic whorl-section of an adult shell, GK. H5461. The secondarily deformed body-whorl is restored.

(T. M. delin.)

stage, as is represented by the hypotype. It is involute, becoming more so as it grows (degree of involution ranging from about $2 / 3$ to $5 / 6$ ). The whorl is higher than broad, growing fairly rapidly in height. It is broadest in the lower part above the umbilical margin. The umbilical wall is steep or nearly vertical and in the last part considerably high, passing to abruptly rounded umbilical shoulders. The flanks are convergent and very gently inflated, forming blunt ventrolateral shoulders with a narrowly arched and carinate venter. The keel is smooth, continuous, and not accompanied with furrows.

Fundamentally the ribs spring in twos or threes from the umbilical tubercles. On some part, however, the shorter ribs tend to be separated from the longer, tuberculate ribs. The umbilical tubercles are more or less bullate. Every rib has a ventrolateral tubercle or thickening, where it is bent forward and fades away as it approaches to the keel. There are eight to ten umbilical tubercles per whorl, whereas the ventrolateral ones are about or slightly less than thirty. The ribs are separated by the interspaces which are as narrow as or slightly broader than the ribs. They are flexiradiate and of moderate intensity on the inner whorl. On the outer whorl the flexuosity becomes indistinct and the ribs and also the tubercles are weakened. On the last part of the adult body-whorl the ribs are almost obsolete on the sides.

The suture consists of $\mathrm{E}, \mathrm{L}, \mathrm{U}_{2}, \mathrm{U}_{4}, \mathrm{U}_{5}(=\mathrm{S}), \mathrm{U}_{3}, \mathrm{U}_{1}$ and $\mathrm{I}$. It is moderately 


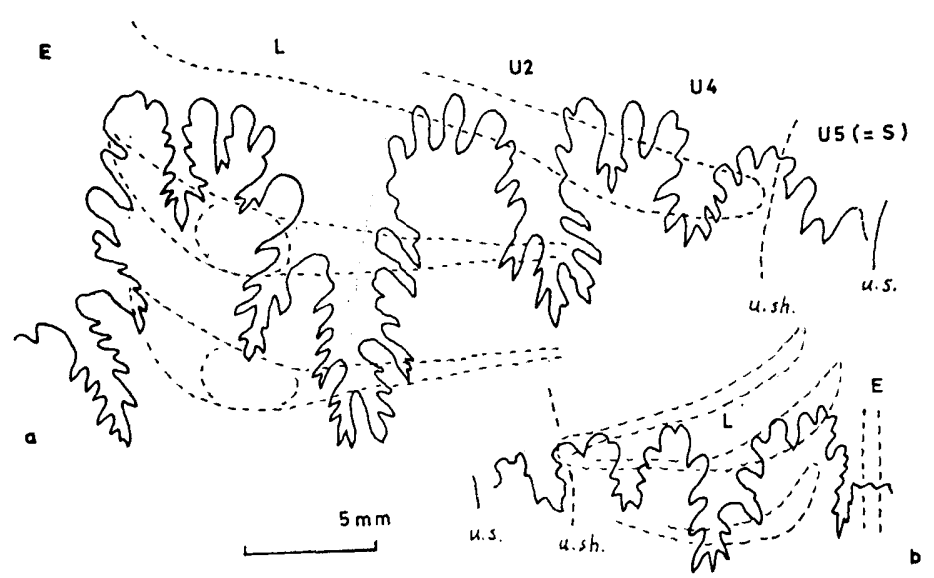

Fig. 2. Pseudobarroisiceras nagaoi SHIMIzU. External sutures of GK. $\mathrm{H} 5461$, in (a) the adult stage at whorl-height $=29 \mathrm{~mm}$. and (b) an immature stage at whorl height $=9 \mathrm{~mm}$. Dotted lines indicate the position of tubercles and ribs. u. sh.=umbilical shoulder; u. s. $=$ umbilical seam.

(T. M. delin.)

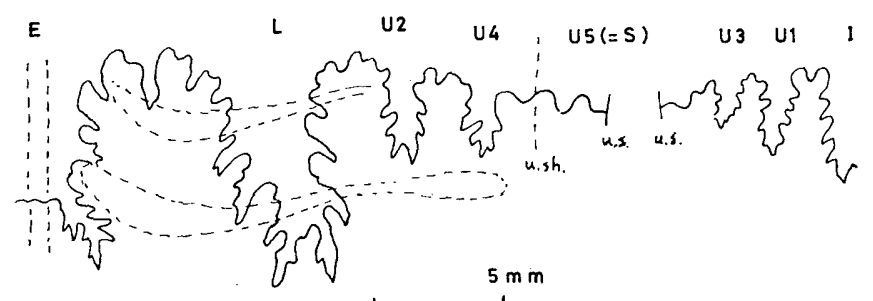

Fig. 3. Pseudobarroisiceras nagaoi SнImizu. Suture of the holotype, IGPS. 36853 , at whorl-height $=14 \mathrm{~mm}$. (External suture T. M. delin.; internal suture after SHIMIzu, 1932).

incised in the adult shell. The lateral lobe (L) is deep and asymmetric, with a longer branch on the outer side. The external lobe $(\mathrm{E})$ is slightly shallower than $L$. The first lateral saddle between $E$ and $L$ is asymmetrically divided by a narrow and moderately deep lobule into a tall and upright outer branch and a somewhat broader and oblique inner one. $\mathrm{U}_{2}$ is much smaller than $\mathrm{L}$. In addition to $\mathrm{U}_{2}$ there are apparently three auxiliary lobes, of which $\mathrm{U}_{4}$ is situated outside the umbilical shoulder.

$\begin{array}{lccrrr}\text { Measurements. } & & & & & \\ \quad \text { Specimen } & \text { Diameter } & \text { Umbilicus } & \text { Height } & \text { Breadth } & \text { B./H. } \\ \text { IGPS. 36853 } & 43.5(1) & 8.3(.19) & 22.5(.52) & 15.9(.37) & .71 \\ \text { GK. H5461 } & 94.0(1) & 13.2(.15) & \sim 51.0(.54) & 33.2(.35) & .65\end{array}$

Comparison.-This species is somewhat similar to a compressed and weakly tuberculate variety of Barroisiceras onilahyense BASSE (1947, p. 100 [4], pl. 12 [6], figs. 2-4 ; Collignon, 1965b, p. 68, pl.444, fig. 1817) from the Coniacian of Madagascar, although the latter species has on the average broader whorls and stronger and coarser ornament than the present species and a distinctly serrate ventral keel. On the immature whorls the ribs are distinctly flexiradiate in the 
present species.

In the same respect and in the rib density as well as in the involute whorls the present species resembles Subprionocyclus normalis (ANDERson, 1958) (see Матsuмото, 1959, p. 118, pl. 29, fig. 1; pl. 31, figs. 1-5; text-figs. 64-66; 1965, p. 55, pl. 12, figs. 1-5; pl. 13, fig. 3; text-figs. 28-33), from the Upper Turonian of California and Japan, but the former has a continuous, unserrate, entire ventral keel and its whorl is not so strongly compressed as the latter. In $S$. normalis the upper ventrolateral tubercle persists and the lower one is discernible only for a limited period of growth-stage; in the present species only a weak tubercle or a thickening is discernible at the bending point of the rib on the ventrolateral shoulder. The sutures of the two species resemble each other in the degree of indentation. The outer branch of the first lateral saddle is unusually reduced in size and lowered in $S$. normalis but such a peculiar feature is not developed in $P$. nagaoi.

The same tendency of the modification in the shape of the first lateral saddle is more strongly manifested in Reesidites minimus (HAYASAKA and FuKADA, 1951) (see Matsumoto, 1965, p. 63, pl. 14, fig. 1; pl. 15, figs. 1-3; text-figs. 34-39), from the top of the Turonian, immediately below the bed with $P$. nagaoi. Furthermore, $R$. minimus has a distinctly serrate keel, clavate upper ventrolateral tubercles, more numerous ribs and much more compressed whorls than $P$. nagaoi. In these respects the two species are not directly related to each other inspite of the closeness in stratigraphic occurrence.

Pseudobarroisiceras nagaoi is apparently similar to Pseudoschloenbachia umbulazi (BAILY) (1855, p. 456, pl. 11, fig. 4; SPATH, 1921, p. 240, pl. 20, figs. 2, 3; text-fig. B2-7; HOEPEN, 1921, p. 35, pl. 8, figs. 6-9 ; pl. 9, figs. 1-2 ; ColligNON, 1966, p. 103, pl.449, figs. 1996-1999; ? HoEPEN, 1968, p. 186, pl.7) from the Santonian of South Africa and Madagascar. The suture of the latter is deeply and finely indented, having an expanded external lobe, a large, trifid lateral lobe with a stem of moderate breadth, and numerous, regularly descending auxiliary elements. In other words, it is of a modified desmoceratid type and is fundamentally different from the Barroisiceras type suture of the present species. In Pseudoschloenbachia umbulazi the whorl is more compressed and more flattened and the ribs are more prorsiradiate near the umbilical margin and show a falciform bending on the flank as compared with the gently sigmoidal ribs of Pseudobarroisiceras nagaoi.

Schloenbachia boreaui DE GRossouvRE (1894, p. 111, pl. 7, fig. 3), from the middle Coniacian of France, which may be referable to Pseudobarroisiceras, is allied to $P$. nagaoi, but has finer, more numerous ribs and more flattened flanks. Its ventral keel is said to be bordered by two furrows, but the furrows do not seem to be so distinct in the illustration. Although I attempted to examine GrossouvRE's specimens in Paris, the holotype of $S$. boreaui was unfortunately missing and we need topotype specimens to make clear the precise systematic position of this rare species.

Occurrence.-This species occurs rarely in Hokkaido. The holotype is reported to have been found by T. NAGAO in the lower course of the Wakkawen, a 
tributary of the Abeshinai, Nakagawa-mura, Teshio province. SHImizu (1932) reported its stratigraphic position as the "Lower Abeshinai Group" in the explanation of plate and as the "middle division of the Abeshinai Group" in the text. According to my geological mapping (MATsumoto, 1942) unit IIIa of the Upper Yezo Group is exposed in the lower course of the Wakkawen. Although I failed to collect the same species in this area, unit IIIa is referred to Coniacian on account of the occurrence of Inoceramus uwajimensis and other species.

T. Muramoto collected a larger, probably adult example of this species at loc. Ik 1003, from the green sandstone at the base of unit IIIa, immediately above the zone of Reesidites minimus, in the Ikushumbets valley, Ishikari province. Accordingly the species is probably of a Coniacian age, although we need the reconfirmation in the Abeshinai area.

\section{Family Vascoceratidae \\ Genus Hourcquia CollignoN, 1965}

Type-species.-Hourcquia mirabilis CoLLIGNoN, 1965 [1965a] (original designation).

Diagnosis.-The shell is moderate in size, and considerably involute. The whorl is more or less inflated and is broadest between the umbilical shoulders. The flanks are convergent and typically have a spiral zone of depression between the row of umbilical tubercles and that of ventrolateral ones. The venter has a strong, entire keel, with a more or less concave, smooth zone on either side.

There are thick tubercles around the umbilicus and more numerous ones on the ventrolateral shoulder. The primary rib arises from the peri-umbilical tubercle and ends at the ventrolateral one. The secondary rib is branched from the primary rib above the umbilical tubercle or inserted on the flank and also ends at the ventrolateral tubercles.

The suture is moderately deeply incised. The ventral lobe (E) is massive and the deepest. The lateral lobe (L) is deeper than broad, asymmetric and apparently multipartite into several lobules. The first and the second lateral saddles are higher than broad, bipartite by a narrow lobule into folioles of dissimilar size. The auxiliaries (U2 and other three lobes) are gradually descending. The folioles show more or less phylloid outline at their terminal.

Remarks.-Hourcquia was established by CollignoN (1965a, p. 77) for the type-species and another species from the Upper Turonian of Madagascar. The species from Saghalien to be described below can be ascribed to the same genus. "Barroisiceras" desmoulinsi DE GROSsOUVRE, 1894, from the Coniacian of France, could be likewise referable to the same genus.

Comparison.-CoLligNON (1965a, p. 77) recognized the affinity of Hourcquia with Masiaposites Collignon, 1965, which, in turn, is allied to Neoptychites Kossmat, 1895. Hourcquia can thus be assigned to the Vascoceratidae. Hourcquia has a more distinct keel, stronger tubercles and somewhat broader lobes of sutures than Masiaposites and Neoptychites.

On the other hand Hourcquia is apparently similar to Subbarroisiceras BASSE, 1946, of the Barroisiceratinae in the aspect of shell-form and ornament, but the 
latter has a serrate keel on the fastigate venter, without concave zone on either side.

Hourcquia resembles Diaziceras Spath, 1921, of the Lenticeratinae in shellform and ornamentation, but the latter has less finely incised, reduced suture in which the first lateral saddle is oblique on the outer side. The venter of Diaziceras is fastigate and has a sharp keel.

Hourcquia pacifica sp. nov.

Pl. 49, Fig. 2; Text-fig. 4

Holotype.-GK. H5203, from the Upper Cretaceous near the colliery of Kawakami, South Saghalien (Coll. S. NAGAOKA).

Description.-The holotype measures about $70 \mathrm{~mm}$. in diameter at the end of

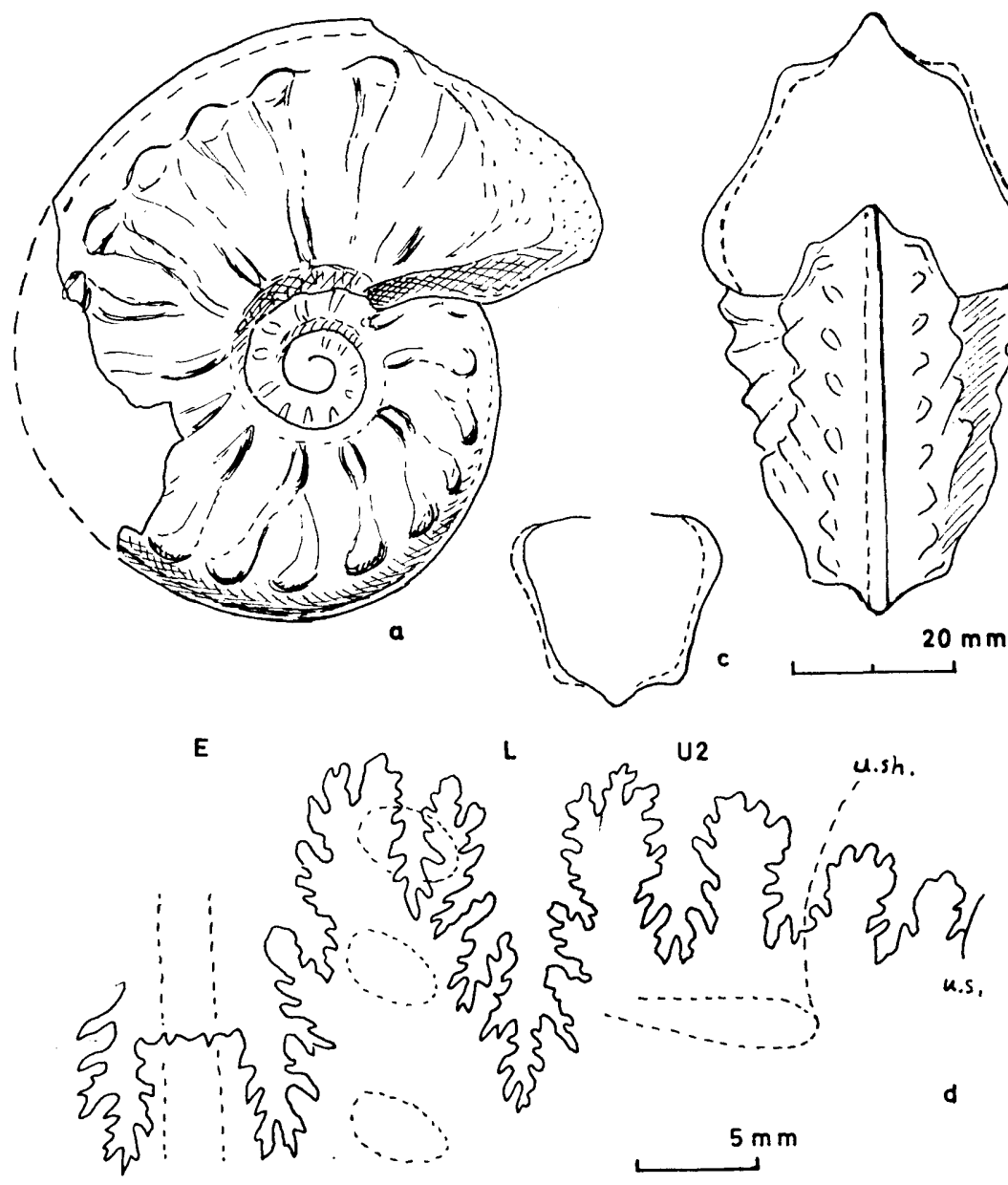

Fig. 4. Hourcquia pacifica sp. nov. Diagrammatic sketch of the holotype, GK. H5203. Lateral (a) and apertural (b) views of the septate shell, another whorl section (c) and the external suture at whorlheight $=20 \mathrm{~mm}$. (d) in which dotted lines indicate the position of tubercles, ribs and a keel.

(T. M. delin.) 
the septate whorl. Although its body-whorl is missing, the shell must have been moderately large at the full-grown stage.

The shell is considerably involute, about three fourths of the inner whorl being concealed by the outer whorl. The umbilicus is fairly narrow and deep, being surrounded by a steep, nearly vertical wall. The whorl is broader than high. The flanks are inflated in the lower part and converge upward, forming shoulders with the strongly carinate venter. The breadth of the venter between the ventrolateral shoulders is about a half of the maximum breadth of the whorl. The ventral keel is thick, entire and bordered with a somewhat concave, smooth zone on either side.

The whorl is strongly ornamented with tubercles around the umbilicus and at the ventrolateral shoulders. The peri-umbilical tubercles are bullate and twelve or so per whorl, whereas the ventrolateral tubercles have a subrounded base, with an obliquely and shortly projected summit, and are nearly twice as numerous as the umbilical ones. The ventrolateral tubercles are disposed alternately on either side of the venter.

The longer ribs, which start near the umbilical seam, are at first weak and rursiradiate on the wall, and then elevated as bullate tubercles on the umbilical shoulder, highest above the umbilical margin, nearly rectiradiate or slightly sinuous on the main part of the flank and alternated with the shorter ribs. Some of the shorter ones may be disposed as if they are bifurcated from the major ones above the umbilical bullae, but others are isolated. Every rib ends at the strong ventrolateral tubercle and does not cross the venter. The ribs are much weakened or even slightly depressed on crossing a spiral zone at some distance below the row of ventrolateral tubercles.

The suture of the adult shell is moderately deeply and finely incised. The ventral lobe ( $\mathrm{E}$ ) is the largest (broadest and deepest) of all the elements. The first lateral saddle between $\mathrm{E}$ and $\mathrm{L}$ is high and asymmetrically bipartite by a considerably deep lobule and the two folioles are again asymmetrically bipartite. The lateral lobe $(\mathrm{L})$ is deeper than broad, having a stem of moderate breadth and narrow branches which are arranged asymmetrically. The second lateral saddle between $\mathrm{L}$ and $\mathrm{U}_{2}$ is fairly slender in aspect and tripartite on the head. $U_{2}$ and other three auxiliary lobes are much smaller than $L$. The auxiliary saddles are regularly aligned on a gently descending line.

\begin{tabular}{lcllll}
\multicolumn{2}{l}{ Measurements.- } & & & & \\
Specimen & Diameter & Umbilicus & Height & Breadth & B./H. \\
GK. H5203 & $71.8(1)$ & $17.1(.24)$ & $33.6(.47)$ & $41.8(.58)$ & 1.24 \\
$(-1 / 2$ vol.) (c) & - & - & 23.5 & 28.2 & 1.20
\end{tabular}

Comparison.-The present species closely resembles Hourcquia mirabilis CoLLIGNON, 1965 (1965a, p. 77, pl. 161, fig. 1709), from the Upper Turonian of Madagascar, but there are some differences. The spiral furrow on the flank is not so distinct in the former as in the latter. The shell is somewhat more narrowly umbilicate in the former than in the latter. The suture of the former is more deeply and more finely indented than in the latter, with deeper lobes and taller lateral saddles, and the phylloid aspect at the terminal of folioles as seen in $H$. mirabilis is almost obliterated in the present species. 

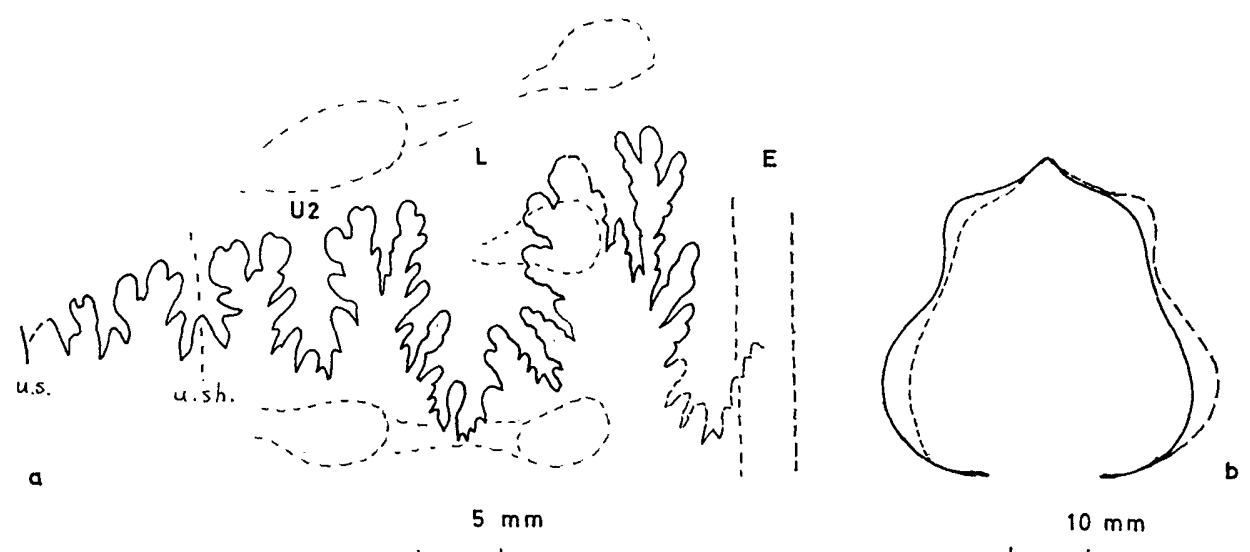

Fig. 5. Hourcquia mirabilis Collingon. Diagrammatic sketch of the holotype, on the basis of the plaster cast sent from M. Collignon.

(a) External suture at whorl-height $=41 \mathrm{~mm}$; ; (b) whorl section.

(T. M. delin.)

Hourcquia pacifica is somewhat similar to Subbarroisiceras mahafalense BAsse (1946, p.71, pl. 2, fig. 1; text-fig. 1; CoLlignon, 1965b, p. 69, pl. 445, fig. 1820 ), from the Coniacian of Madagascar. But in the latter, as in most species of the Barroisiceratinae, the keel on the fastigate venter is distinctly serrate and not bordered by a smooth concave zone, and the ventrolateral tubercles are clavate from which weak ribs run forward toward the keel. The suture of $H$. pacifica is as finely and deeply indented as that of $S$. mahafalense, but the two species differs in the details of the pattern (compare text-fig. 40 of this paper with text-fig. 1 of BASSE, 1946).

It is unlikely that the serrated keel of Subbarroisiceras was derived from the entire keel of Hourcquia. I would not take the origin of the Barroisiceratinae in the Vascoceratidae. Barroisiceras is more intimately connected with Subprionocyclus of the Collignoniceratinae, as has already been explained (WRIGHT, 1957, p. L432; REYMent, 1955, p. 67 ; MATSUmoto, 1969, p. 298).

H. pacifica is apparently similar to Diaziceras tissotiaeforme SPATH (1921, p. 245, pl. 19, fig. 1), from the Senonian of Zululand (South Africa) and Diaziceras spathi HourcQ (1949, p. 107, pl.12, fig. 2), from the Senonian of Madagascar, in its shell-form, smooth and persistent keel, and ornament. The suture of the latter two species is of simplified type, with more distinctly phylloid terminals of the folioles, and the modified first lateral saddle which is oblique on the outer side. In other words it is of Lenticeras type and is much different from the suture of H. pacifica.

The specimen described as the type of Barroisiceras haberfellneri var. desmoulinsi DE GRossouVRE (1894, p. 56, pl. 2, fig.6) represents a species which is distinct from Barroisiceras haberfellneri (HAUER) in its much inflated, broad whorl and strong tubercles. Although DE GRossouvRe attributed the smoothness of its keel to the unfavourable state of preservation, this seems to be an original 
character. If it is so, the specimen can possibly represent a species of Hourcquia, although its suture is not exactly known. H. (?) desmoulinsi, from the Coniacian of France, has less numerous and much stronger tubercles than $H$. pacifica.

Occurrence.-The locality is roughly recorded as the vicinity of the Kawakami colliery, South Saghalien. From the lithology of the fossil in a calcareous mudstone nodule the specimen is judged to have come from the Miho Group (Turonian-Santonian), but further precise stratigraphic position is not known. Its assignment to Hourcquia suggests an Upper Turonian age, but a Coniacian age could be considered as another possibility, because its suture is more complex than that of $H$. mirabilis and because it resembles $H$. (?) desmoulinsi. The uncertainty should be made clear by careful collecting in the future.

\section{Concluding Remarks}

Since NeUmaYr (1875) introduced Schloenbachia, this generic name has been used too much comprehensively for the Cretaceous keeled ammonites. In our present knowledge the ventral keel appears in a number of stocks which are not necessarily related with one another. The Schloenbachiidae in the true sense are of hoplitid stock, occurring mainly in the Cenomanian, but did not further give rise to other Upper Cretaceous keeled ammonites. Nor do they have genetic affinity with the Brancoceratidae of the Albian, whose origin is not in the hoplitid but probably in the Desmoceratidae through such genera as Callizoniceras or Miyakoceras (CASEY, 1957; OBATA, 1967). The Mortoniceratinae of the Brancoceratidae include several genera or subgenera which are homoeomorphic with some genera of the Senonian Texanitinae.

Of the Upper Cretaceous keeled ammonites the Collignoniceratidae occupy the majority. As their keel was derived from the train of the ventral tubercles of the Acanthoceratidae, it is strongly or distinctly serrate in all the Collignoniceratinae of mainly Turonian and partly Coniacian ages. The Coniacian Barroisiceratinae, which were derived from Subprionocyclus of the Collignoniceratinae, essentially have a serrate keel on the fastigate venter.

On the other hand the ventral keel is nearly or completely entire and continuous in most genera of the Senonian (Coniacian to Campanian) Peroniceratinae, Texanitinae and Lenticeratinae. As I have already discussed (MAtsumoto, 1955 ; 1965), the Peroniceratinae were probably derived from Prionocyclus through Gauthiericeras, the Texanitinae from Subprionocyclus through Protexanites, and the Lenticeratinae from a certain group of Subprionocyclus through (?) Niceforoceras.

Pseudobarroisiceras described in this paper is closely allied to and probably derived from Barroisiceras. As I have explained in another paper (MATsumoto, 1969), in certain genera and subgenera of the Barroisiceratinae, e.g. Solgerites, Muramotoa and Yabeiceras, the serration of the keel becomes indistinct or lost on the outer whorl on which a low keel may or may not remain and ribs and tubercles are also weakened. In Pseudobarroisiceras, however, the keel is entire already in the distinctly costate immature stage. If Pseudobarroisiceras gave rise to more 
genera with an entire keel, it could be grouped with them in a new subfamily. In our present knowledge there are not such examples. Therefore I think it better to ascribe Pseudobarroisiceras tentatively to the Barroisiceratinae, although it is atypical. Anyhow, it should be noted that some members of the Barroisiceratinae can give rise to ammonites with an entire keel.

In this connexion discussion should be extended to the similarity between Pseudobarroisiceras and Pseudoschloenbachia. As I have mentioned in the description, Pseudobarroisiceras is somewhat similar to Pseudoschloenbachia, but the similarity is in my opinion superficial, because the two genera are fundamentally different in the pattern of sutures. The suture of Pseudobarroisiceras is essentially similar to that of Barroisiceras, whereas that of Pseudoschloenbachia is of desmoceratoid type, as clearly illustrated by SPATH (1921, p. 241, text-fig. B) and VAN HOEPEN (1921, p. 36, text-figs. 17, 18).

CoLlignoN (1966b) has recently shown in an atlas numerous examples of Praemuniericeras, Muniericeras, Pseudoschloenbachia and Lehmaniceras from the Santonian of Madagascar and suggested that these closely related genera should be grouped into one and the same family. This implies that Pseudoschloenbachia should be ascribed to the Muniericeratidae WRIGHT, 1952. This family includes also Turonian to Coniacian Tragodesmoceras and is considered as a branch from the Desmoceratidae through Tragodesmoceroides.

I generally agree with COLLIGNON in this assignment of Pseudoschloenbachia. Praemuniericeras, Muniericeras and Lehmaniceras have distinct crenulations or clavate tubercles on the siphonal line of the fastigate venter, whereas the ventral keel is distinct and nearly or completely smooth in Pseudoschloenbachia. The latter genus seems to have been developed into a number of subgenera in the Santonian to Campanian ages, as is preliminarily informed by CoLLIGNoN (1966, p. 15). Accordingly the separation into two subfamilies can be taxonomically justified. The former group is called the Muniericeratinae. To the latter the Pseudoschloenbachiinae vAN HOEPEN, 1968, can be applied, although HoEPEN proposed it as a subfamily of the Collignoniceratidae.

It is interesting to see that Pseudoschloenbachia (Fournierella), a constricted and rather weakly ornamented subgenus, is in many respects similar to Hauericeras, a member of the Desmoceratidae with a fastigate and carinate venter. An example of more distinctly keeled desmoceratid is Damesites, from which these genera are clearly distinguished.

Texasia ReEside, 1932, which I (MATsumoto, 1969, p. 300) have excluded from Barroisiceras on account of its deeply incised sutures with trifid lateral lobe and evolute, flat-sided whorls, is closely allied to Lehmaniceras. It can be distinguished from Lehmaniceras only by the absence of a smooth zone between the row of ventral clavi and that of ventrolateral tubercles. It is also allied to Muniericeras but has stronger ventrolateral tubercles and a higher ventral keel and its ribs are not so remarkably projected at the periphery as in Muniericeras. Texasia should thus be removed from the Barroisiceratinae of the Collignoniceratidae to the Muniericeratidae.

Another species described in this paper under Hourcquia pacifica is interest- 
ing in that it looks as if it were a derivative of Subbarroisiceras that acquired a smooth keel. Actually it is not so, and the similarity is superficial. It is most closely allied to Hourcquia mirabilis CollignoN. Hourcquia is strongly keeled, costate and tuberculate, but has a close affinity with Masiaposites and, in turn, with Neoptychites and Thomasites. It is, thus, an uncommon keeled offshoot of the Vascoceratidae. The Barroisiceratinae are not directly connected with this branch of the Vascoceratidae, inasmuch as their origin is best sought in $S u b$ prionocyclus. The similarity between Hourcquia and Diaziceras is again homoeomorphic, since Diaziceras is taken as a member of the Lenticeratinae on account of its particular pattern of suture and fastigate and acutely keeled venter.

In conclusion keeled ammonites of the Cretaceous are polyphyletic. The two uncommon species described in this paper give additional examples of the homoeomorphy.

Acknowledgements.-I thank Messrs. Tatsuo Muramoto and Shozo NaGaoka who put at my disposal the interesting ammonites. Professor Kotora HATAI of Tohoku University and Professor K. J. MÜLLER and Professor H. K. ERBEN of the University of Bonn generously let me study freely the type-specimens in the respective institutes. I very much appreciate valuable information of the ammonites of Madagascar provided by Madam Eliane BASSE and General Maurice Collignon. Dr. Jacques SoRnaY of the National Museum of Natural History in Paris and General Collignon have kindly provided me with plaster casts of several type specimens. Dr. Itaru HAYAMI and Miss Yuko WADA assisted me in preparing the manuscript.

\section{References Cited}

Anderson, F. M. (1958): Upper Cretaceous of the Pacific Coast. Geol. Soc. Amer., Memoir, 71, 378p., 75 pls.

BaILY, W. H. (1855): Description of some Cretaceous fossils from South Africa. Quart. Jour. Geol. Soc. London, 11, 454-465, pls. 11-13.

BASSE, Eliane (1946): Sur deux ammonites nouvelle du Coniacien du sud-ouest de Madagascar: Subbarroisiceras n.g. mahafalense n. sp. et Eboroceras n.g. magnumbilicatum n. sp. Bull. Soc. Géol. France, [5], 16, 71-76, pl. 2.

(1947): Les peuplements Malgaches de Barroisiceras (Revision du genre Barroisiceras DE Gross.). Paléontologie de Madagascar 26. Ann. Paléont., 33, 97-190, pls. $7-14[1-8]$.

CASEY, Raymond (1957): The Cretaceous ammonite genus Leymeriella with a systematic account of its British occurrences. Palaeontology, 1, (1), 28-59 pls. 7-10.

Collingon, Maurice (1865a): Atlas des fossiles caracteristiques de Madagascar (Ammonites), 12 (Turonien), 1-82, pls. 376-413, Serv. Géol., Tananarive. (1965b): Atlas des fossiles caracteristiques Madagascar (Ammonites), 13 (Coniacien), 1-88, pls. 414-454, Serv. Géol., Tananarive.

(1966): Atlas des fossiles caracteristiques de Madagascar (Ammonites), 14 (Santonien), 1-134, pls. 455-513. Serv. Géol., Tananarive.

Grossouvre, Albert DE (1894): Recherches sur la Craie supérieur. II Paléontologie. Les ammonites de la Craie supérieur. Mém. Carte Géol. Dét. France [1893]. $264 \mathrm{p} ., 39 \mathrm{pls}$.

HAYASAKA, Ichiro, and FUKADA Atsuo (1951): On the ontogeny of Barroisiceras mini- 
mum YABE from the Upper Ammonite bed in Hokkaido. Jour. Fac. Sci., Hokkaido Univ., [4], 7, 324-330, pls. 1-2.

HoEpen, E. C. N. van (1921): Cretaceous cephalopods from Pondoland. Ann. Transvaal Museum, 8, (1) 1-48, pls. 1-11.

(1968): New ammonites from Zululand. Ann. Geol. Surv. S. Afr., 4 (1965), 183-191, incl. pls. 1-7.

HourcQ, Victor (1949): Sur quelques ammonites du Sénonien. Paléontologie de Madagascar 28. Ann. Paléont., 35, 87-117, pls. 11-13.

Kossmat, Frantz (1895): Untersuchungen über die Südindische Kreideformation, I. Beitr. Paläont. Geol. Osterr.-Ungarns u.d. Orients, 9, 97-203 [1-107], pls. 15-25 [1-11].

Matsumoto, Tatsuro (1942): Fundamentals in the Cretaceous stratigraphy of Japan. Part I, Mem. Fac. Sci., Kyushu Imp. Univ., [D], 1, 129-280, pls. 5-20.

(1955): Evolution of Peroniceratidae. Trans. Proc. Palaeont. Soc. Japan, [N.S.], (18), 37-44.

(1959): Upper Cretaceous ammonites of California. Part II. Mem. Fac. Sci., Kyushu Univ., [D], Special vol. 1, 1-172, pls. 1-41.

(1965): A monograph of the Collignoniceratidae from Hokkaido. Parts I \& II. Mem. Fac. Sci., Kyushu Univ., [D], 16, 1-80, pls. 1-18 [Part I]; 209-243, pls. 36-43 [Part II].

(1969-70): A monograph of the Collignoniceratidae from Hokkaido. Part III. Ibid., 19, 297-330, pls. 39-45; Part IV. Ibid., 20, 225-304, pls. 30-47.

Neumayr, Melchior (1875): Die Ammoniten der Kreide und die Systematik der Ammonitiden. Zeitschr, deutsch. geol. Gesell., 27, 854-892.

ObatA, Ikuwo (1967); Lower Cretaceous ammonites from the Miyako Group. Part 2, Some silesitids from the Miyako Group. Trans. Proc. Palaeont. Soc. Japan [N. S.], (67), 129-138, pl. 11.

ReEside, J. B. Jr. (1932): The Upper Cretaceous ammonite genus Barroisiceras in the United States. U. S. Geol. Surv., Prof. Paper, 170-B (for 1931), 9-29, pls. 3-10.

Reyment, R. A. (1955): The Cretaceous Ammonidea of southern Nigeria and the southern Cameroons. Bull. Geol. Surv. Nigeria, 25, 112p., 25 pls.

Shimizu, Saburo (1932): On a new type of Senonian ammonite. Pseudobarroisiceras nagaoi SHrmizu gen. et sp. nov. from Teshio Provience, Hokkaido. Japan. Jour. Geol. Geogr., 10, 1-4, pl. 1.

Spath, L. F. (1921): On Cretaceous Cephalopoda from Zululand. Ann. S. Afr. Museum. 12, (7), 217-321, pls. 19-26.

Wright, C. W. (1952): A classification of the Cretaceous ammonites. Jour. Paleont., 26. (2), 213-222.

(1957): IN MOoRE R. C. [Editor]: Treatise on Invertebrate Paleontology, Part L. Mollusca, Cephalopoda, Ammonoidea, L1-L490, Geol. Soc. Amer. \& Univ. Kansas Press. 
Tatsuro Matsumoto

Uncommon Keeled Ammonites from the Upper

Cretaceous of Hokkaido and Saghalien

Plates 48-49 
Plate 48 


\section{Explanation of Plate 48}

Fig. 1. Pseudobarroisiceras nagaoi Shimizu.......................... 306 Hypotype, GK. H5461 [=T. MURAmoto Coll. 9300], from loc. Ik 1003, green sandstone of Illa, Ikushumbets valley, Ishikari Province, central Hokkaido Two lateral $(a, b)$, ventral (c) and apertural (d) views, $\times 1$. Kyushu University (I. HAYAMI) photos, without whitening. 

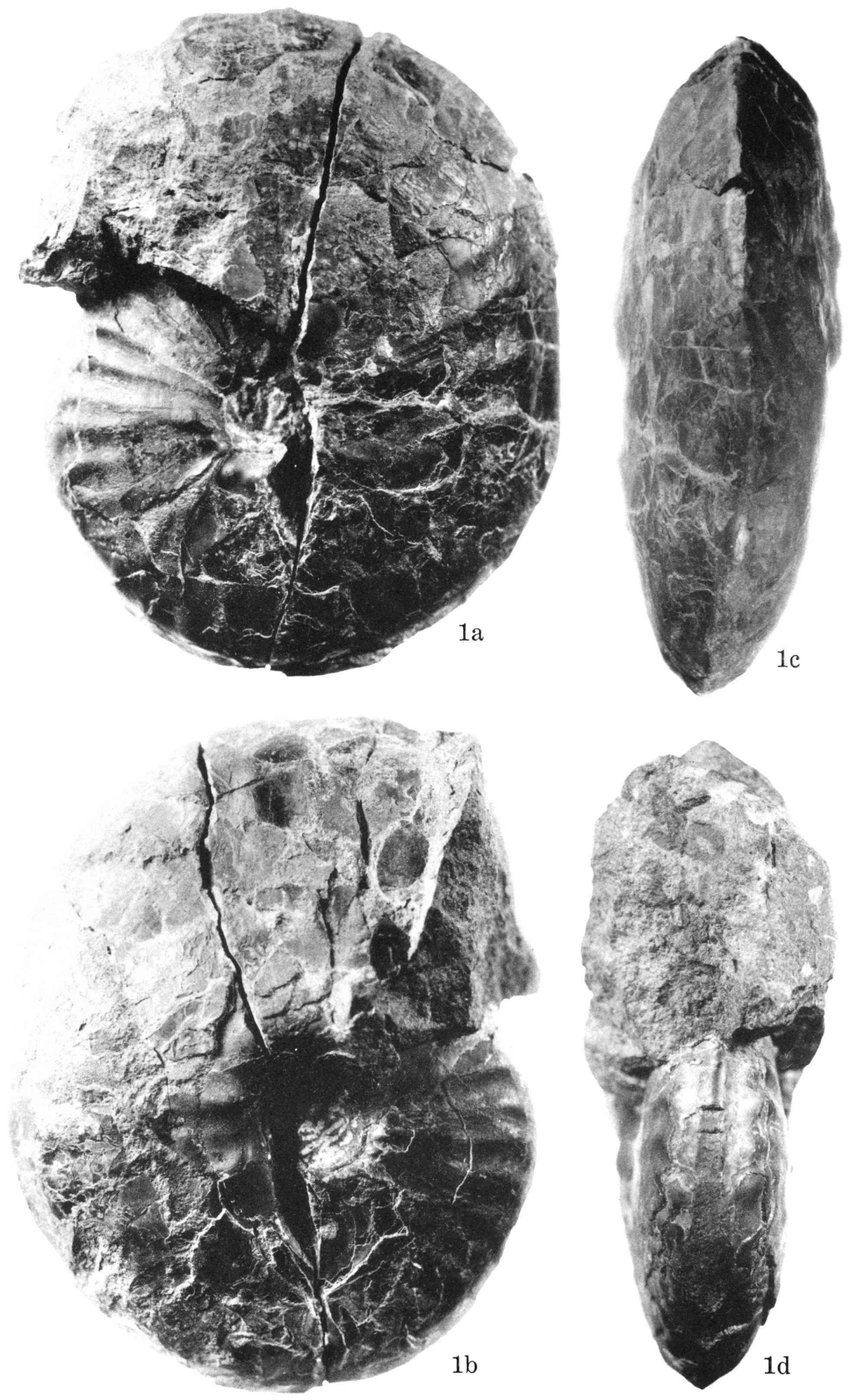

T. Matsumoto: Uncommon Keeled Ammonites 
Plate 49 


\section{Explanation of Plate 49}

Fig. 1. Pseudobarrosiceras nagaoi Shimizu......................... 306 Holotype, IGPS. 36853 [T. NAGAo Coll.], from the lower course of the Wakkawen, a tributary of the Abeshinai, Teshio Province, northwestern Hokkaido. Two lateral $(a, b)$, ventral (c) and apertural (d) views, $\times 1$. Tohoku University (K. KUMAGAI). photos, without whitening.

Fig. 2. Hourcquia pacifica sp. nov.........................Page 311 Holotype, GK. H5203 [S. NAGA0KA Coll.], from the Upper Cretaceous near Kawakami colliery, South Saghalien, $\times 1$. Kyushu University (I. HAYAMI) photos, without whitening.

IGPS.=Institute of Geology and Palaeontology, Tohoku University, Sendai. GK.=Department of Geology, Kyushu University, Fukuoka. 

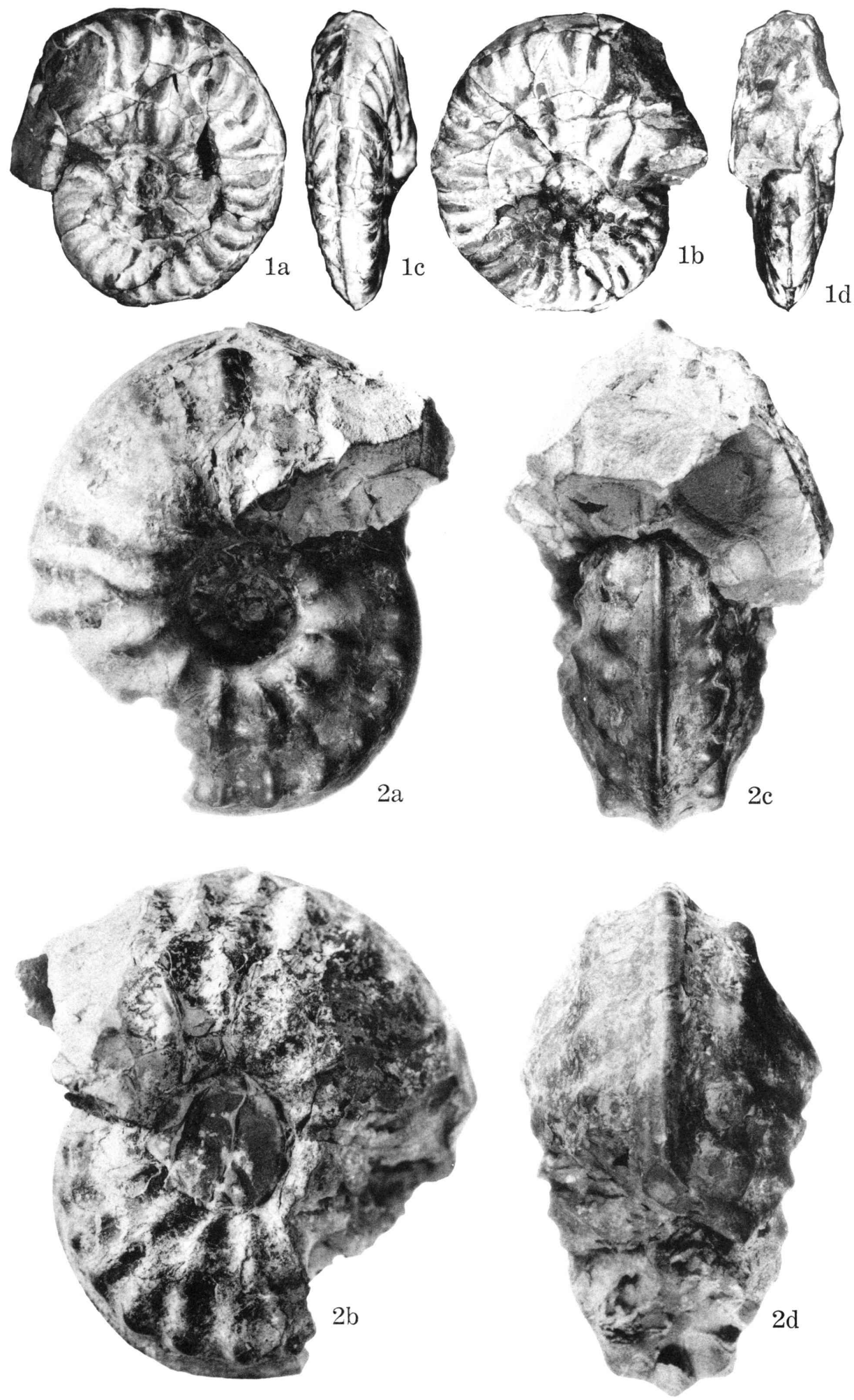

T. Matsumoto: Uncommon Keeled Ammonites 